Dor: http://dx.doi.org/10.11157/sites-vol14issiid345

- ARTICLE -

\title{
CARCERAL RECOGNITION AND THE COLONIAL PRESENT AT THE OKIMAW OHCI HEALING LODGE
}

\author{
Margaret Boyce ${ }^{1}$
}

\begin{abstract}
This essay examines how unchecked recognition-based policies in Correctional Service of Canada's (CSC) mandate - such as the utilisation of 'traditional healing' in penal programming and the construction of prisons designed solely for Indigenous inmates - undermine the needs of Indigenous people in prison, while propagating settler-colonialism through the often invisible mechanisms of the prison system. By way of an analysis of the Okimaw Ohci Healing Lodge federal prison for Indigenous women, in Maple Creek, Saskatchewan, I identify the emergence of a carceral recognition politics in Canadian prisons. This term refers to a strategy whereby the penal system parades its willingness to accommodate Indigenous difference in order to reconcile Indigenous peoples with the authority of the State - often through the implementation of colonial teleologies towards a supposedly non-colonial present - while simultaneously developing a durable and comprehensive prison system for the more effective incarceration of federally sentenced Indigenous women.
\end{abstract}

Keywords: Indigenous incarceration; colonialism; recognition; Canadian prisons

\section{INTRODUCTION}

While many in Canada celebrate the nation-state's newfound proclivity for 'strengthening recognition' of Indigenous peoples and their demands (Assembly 2005, 18), others are critical of the State's shift towards ostensibly inclusive and empowering forms of engagement and exchange. Recent sovereigntist texts, such as Glen Coulthard's Red Skin, White Masks (2014), argue that the Canadian State utilises reconciliation and accommodation to deploy a colonial politics of recognition in order to undermine comprehensive demands for Indigenous sovereignty. However, whereas Coulthard, Taiaiake Alfred (2005, 2009), and others interrogate the parochial forms of inclusion that the State 
promotes, such critiques of recognition tend not to extend to a concurrent movement within the Canadian prison system. In fact, Correctional Service of Canada's (CsC) reformed policies vis-à-vis federally-sentenced Indigenous women seem to exemplify the current recognition-based colonial project, particularly as the State agency now tends to characterise accommodating and recognising Indigenous difference as foundational for determining how best to incarcerate Indigenous women.

Exploring prison policy, government reports, as well as video representations of federally-sentenced Indigenous women in Canada, this article demonstrates that a carceral recognition politics is currently at work in the Canadian prison system. Csc deploys recognition of the particular needs of Indigenous women through the rhetoric of 'healing' and requests that Indigenous women take responsibility for their incarceration while simultaneously denying the continued existence of the very colonial policies that contribute to their incarceration. As a result, federally-sentenced Indigenous women are compelled to perform a normative transition from a traumatic past to a 'healed' present that elides the persistence of colonialism today - which implicates them in dramatising what Coulthard calls a 'colonial present'. Moreover, csc fabricates a normative bond between Indigenous women in prison and the colonial prison system, creating a parallel transition: Indigenous women move towards 'healing' in prison while the Canadian prison system seems to transition into an ideal, Indigenous-sensitive present, leaving all colonial wrongs in the past. Given the clear relationship between the politics of the prison system and the lives of individual women, this essay requests that we consider both the political and personal significance of incarcerating Indigenous women under a regime of recognition politics. The disproportionate rate at which the State incarcerates Indigenous people - and Indigenous women in particular - suggests that illuminating the colonial machinations of CsC is necessary for any decolonial and social justice work in Canada. ${ }^{3}$ The prison system is not simply another 'example of the oppression of First Nations People under a system' to which they 'never consented' (Task Force on Federally Sentenced Women 1990, 23), but one that contributes to and supports - perhaps in ways that only a prison system can - the overarching system of settler-colonialism in Canada today.

RECOGNISING 'INDIGENOUS DIFFERENCE' AND OPERATIONALISING OKIMAW OCHI

The Okimaw Ohci Healing Lodge in Maple Creek, Saskatchewan stands out as a clear example of recognition-based policies at work in the Canadian prison system. The healing lodge emerged in the late twentieth century, when feminist 
and anti-prison activist groups, such as the Canadian Association of Elizabeth Fry Societies (CAEFS), were increasingly raising concerns about the techniques that Canada uses in its administration of women in prison. Canada's two-tier correctional system is often identified as a problem: women serving more than two years are known as 'federally sentenced', whereas those with a lesser penalty are relegated to provincial prisons, meaning that, until 1995, all federallysentenced women served their sentence at the Prison for Women (P4W) in Kingston, Ontario, regardless of where in Canada they - and thus their friends and family - resided (Hannah-Moffat and Shaw 2000, 17). At P4W there were 'no minimum-security facilities, no facilities for mothers with babies nor even specific psychiatric facilities for women serving long sentences' (p.18). Eventually, calls for investigations into the conditions at $\mathrm{P} 4 \mathrm{~W}$ - with particular attention on how federal imprisonment is inadequate in general, but more so for women - led to the founding of the Task Force on Federally Sentenced Women (TFFSW) in 1989. The task force produced a document entitled Creating Choices (1990), which advised CsC to close P4W and build 'five new regional facilities and a healing lodge for Aboriginal women, as well as the parallel development of a community-release strategy' (Hannah-Moffat and Shaw 2000, 21). The need for a healing lodge emerged from the task force's conclusion that the current mode of federal imprisonment discriminated against Indigenous women two-fold: it did not accommodate their particular needs as women, nor did it address their particular requirements as members of Indigenous nations. In 1995, CsC deferred to the task force and built the aboriginal healing lodge' - Okimaw Ohci. The lodge now stands on Nekaneet First Nation land, in southern Saskatchewan, near Maple Creek. It is the first prison in Canada that houses only Indigenous women, and it administers only to those serving a federal sentence (two years or more), with accommodation for thirty women and ten children. Okimaw Ohci is undoubtedly a victory from many perspectives, with Ellen Adelberg and the Native Women's Association of Canada (NWAC) stating that 'the healing lodge represents an important innovation for Canada's corrections' (1993, 91).

Creating Choices called for programmes designed around the interrelated nature of a woman's experience' (TFFSW 1990, 105) that 'reflect the wishes and needs of individual women' (Hannah-Moffat and Shaw 2000, 22), but the report also proposed objectives in accordance with an 'Indigenous resurgence' ethos insofar as it brought attention to the multiple and overlapping 'systems of dispossession that shape Indigenous peoples' experiences' (Coulthard 2014, 176). If we view Okimaw Ohci as a concrete example of csc's apparent eagerness to accommodate 'Indigenous difference', then we must also consider how the operationalisation of the lodge itself, as well as the discursive formation 
surrounding colonial recognition politics more broadly, might allow for a seemingly progressive approach to incarceration that nevertheless maintains a 'relationship between Indigenous peoples and the state' that is 'colonial to its foundation' (Coulthard 2014, 6; emphasis in original).

Coulthard does not deal with Indigenous incarceration as such, but the four tenets of his theory are invaluable for identifying how Okimaw Ohci remains 'reconcilable with one political formation - namely, colonial sovereignty' (2014, 66) - and thus for elaborating a theory of carceral recognition politics at play in the Canadian penal system. First, in colonial recognition politics, the State offers menial concessions, which only have to appear to represent a sufficient response to the systemic oppression of Indigenous peoples in Canada. Second, the State's concessions provide the (false) sense that the traumas of colonialism exist entirely in the past, naturalising a colonial account of history while perpetuating a 'colonial present'. Diverting activist objectives and situating colonialism in the past provides for the final two purposes of colonial recognition politics: establishing and maintaining asymmetrical modes of exchange between Indigenous peoples and the State; and affirming the authority of settler-colonial governance - in other words, material subordination and political subordination. Moreover, colonial recognition of 'Indigenous difference' not only appropriates and modifies activists' objectives in order to undermine the transformative potential of Indigenous peoples' dissent, but operates in such a way as to appear to align with activists' demands.

SYSTEMATISING SETTLER-COLONIALISM THROUGH CARCERAL RECOGNITION

Canada's recognition of Indigenous difference in the prison system - here referred to as carceral recognition - occurs within a longer history of prison reform, which has frequently been driven by advocacy and political discourse stipulating that the State needs to recognise and respond to the demands of Indigenous peoples. In the 1970s, Indigenous prison advocate Art Solomon successfully compelled the State to allow First Nations prisoners to hold ceremonies (Faith 2006, 291), and in 1975 the Commissioner of Penitentiaries officially recognised Native Sisterhoods as a 'self-help program' (Zellerer 1992, 257). Historically, advocates for Indigenous prisoners had to struggle for CsC to allow sacred items and ceremonies into prisons, and each victory was tenuous (Faith et al. 1990, 185). Hence, the acceptance of the value of Indigenous practices seems to signal a move away from assimilationist policies based on the idea that Indigenous cultures are inferior, pagan, etc. It is not surprising, then, that Sharon McIvor, an Indigenous prison activist for the Native Women's Association of Canada (NWAC), was pleased when the Solicitor General 'totally 
agreed' with the NWAC's suggestions for implementing Okimaw Ohci, reporting that they had 'no problem dealing with Corrections' (Adelberg and Currie 1993, 88). Given its previous reluctance to enact any sort of meaningful change to accommodate Indigenous prisoners, Canada's attempt to draft a new and feminist-based prison system is remarkable (Hannah-Moffat and Shaw 2000, 15). From a perspective suspicious of the State's recognitionist manoeuvrings, however, it seems clear that CSC and the Solicitor General were amenable to the recommendations made by TFFSw, insofar as the State's interpretation of Creating Choices did not require it to relinquish its authority to put Indigenous women behind bars.

Csc might offer concessions for Indigenous women via the building of Okimaw Ohci, but its inadequate execution of its own policies effectively undermines the objectives of the TFFSW, while also renewing the State's authority to incarcerate the women in question with impunity. In 1992, CsC developed the Corrections and Conditional Release Act (CCRA), which includes guidelines for the 'care, custody and release' of Indigenous people in conflict with the law (Canada Government 1992). According to a 2012 report by the Correctional Investigator for Canada, Howard Sapers, the Aboriginal-specific provisions of the CCRA are a natural and progressive extension of section 35 of the Canadian Constitution' - the section that famously acknowledges the treaty rights of Indigenous peoples in Canada (Sapers 2012, 9). Many of the criticisms levelled against Canada's penal system pertain to its failure to fulfil the stipulations of the CCRA. Section 81, for example, stipulates that CSC 'may enter into an agreement with an aboriginal community for the provision of correctional services to aboriginal offenders and for payment $[\ldots]$ in respect of the provision of those services' (Sapers 2012, 8). Section 84.1 ascertains that certain 'offenders' may be released, under supervision, to an 'aboriginal community' (p.9). The NWAC has suggested that better utilisation of Section 81 would enable First Nations communities to 'establish community-based healing facilities' for Indigenous women in prison (McIvor and Johnson 2003,3).

In essence, CCRA's provisions could link 'inside' (incarcerated) communities with 'outside' communities, both in terms of resources and administration, but also by joining Indigenous legal practices with other elements of Indigenous self-determination. However, while the CCRA came into effect in 1992, today there are only four independent 'Aboriginal healing lodges' in Canada and no section 81 healing lodges for women (Sapers 2012, 34). ${ }^{4}$ While CsC's original intent was to provide 'an intermediate step' for transferring control of Okimaw Ohci to the Nekaneet under Section 81, negotiations between CsC and the Nekaneet First Nation never proceeded beyond the preliminary stages (p.23). 
Today, the Nekaneet have taken a 'hands off' position, based on concerns that Okimaw Ohci has 'moved away from the community's vision of a healing lodge' (pp.23-24). csc's failure to apply Section 81 to Okimaw Ohci thus enacts a compartmentalisation of Indigenous objectives: in exchange for developing alternatives that accommodate 'Indigenous difference', the prison system continues to prevent Indigenous communities from developing more holistic modes of self-determination, such as practices that include non-colonial, sovereign forms of justice - a manoeuver that hinges on recognition. Despite some deference to 'Indigenous difference', it would seem that CSC and the CCRA are 'still colonial insofar' as they are 'structurally committed' to marginalising federally-sentenced Indigenous women (Coulthard 2014, 151; emphasis in original), as well as undermining the autonomy of Indigenous governments like the Nekaneet.

Participants in the TFFSW now acknowledge that compromise and 'good faith' typified much of their work, meaning that Creating Choices is 'not the visionary document that the CSC now describes it to be' (Faith and Pate 2000, 141). Andrea Smith stipulates that compromise is actually characteristic of advocating for change, in part because struggles for 'social transformation' typically occur 'within the terms set by the current system. Normative conditions tend to prevail when advocates of change must formulate an imagined future that complies with the terms of the present (Smith 2014, 223). And prisons actually embody a structural capacity for reform. In the words of Michel Foucault, "reform" is virtually contemporary with the prison itself: it constitutes, as it were, its programme' $(1979,234)$. Without the understanding that recognition serves to affirm colonialism, csc could be viewed as simply utilising its inherent capacity for adaptation in order to concretise its mandate vis-à-vis incarcerating Indigenous women. Canada's 'innovative' approach to Indigenous incarceration, for example, models Pat Carlen's concept of 'carceral clawback', whereby the penal system perpetuates itself by offering trivial reforms in response to prison advocates' demands (Carlen 2002, 117). However, do revelations about the penal system's malleability fully apprehend the extent to which a colonial prison system is tasked with maintaining the 'settler-colonial relationship' between Indigenous peoples and the State (Coulthard 2014, 6)? Examining the administration of Okimaw Ohci, as well as the discursive and social effects of its policies, gives a sense of how prison reform and what I term carceral recognition simultaneously intervene in the lives of Indigenous women in particular, as well as how they overlap with, inform, or otherwise mobilise the multiple and interrelated recognition-based tactics that undergird contemporary settler-colonialism in Canada. 
Csc's recognitionist appropriation of activists' objectives has led to a form of policy-making regarding healing lodges that entangles the concept of 'Indigenous difference' with the notion that Indigenous prisoners require 'healing. Today, settler-colonialism in Canada thrives on what Sam McKegney terms 'the reification of the healing industry' $(2005,85)$ - a set of capitalist and colonialist strategies that proffer healing from the past to distract from immediate injustice. csc's affinity for the rhetoric of 'healing' has a temporal thrust. In distorting TFFSW's objectives into a push towards 'healing', CsC enacts a 'colonial present', using carceral recognition to fabricate a 'transition from an authoritarian past to a democratic present' and thus 'narrowly situate the abuses of settler colonization firmly in the past' (Coulthard 2014, 22; emphasis in original). Moreover, prioritising 'healing' distracts from the 'diversity of interlocking oppressive social relations that constitute' settler-colonialism in Canada (p.15).

A csC report from 1998 regarding incarcerated Indigenous individuals from urban environments lists a variety of 'needs presented by clients', which stem from several origin points: childhood abuse, often severe; unstable home and family lives; lack of reliable housing or a tendency towards transience; alcohol abuse; and chronic unemployment (Canada Government 1998, 31). The 2004 Program Strategy for Women Offenders lists csc's 'Guiding Principles for the design of Aboriginal Programs for Women', which include the need to 'address the prevention of criminal behavior' using 'culturally appropriate and genderspecific' methods (Fortin 2004, 21). In the world of csc, the need to heal is interchangeable with the 'unique concerns of Aboriginal women' (Canada Government 1998, 19). The Office of the Correctional Investigator's (OCI) own criticism of csc does little to undo the conflation of brokenness with Indigeneity, contending instead that CsC can stem the flow of Indigenous women into prison if it commits to better supporting 'healing' in its lodges (Sapers 2012).

In addition to the fact that csc uses recognition to locate federally-sentenced Indigenous women on a temporal trajectory from a problematic past to a supposedly 'healed' non-colonial present, Okimaw Ohci is instrumental in binding Indigenous women and the State in seemingly parallel progressions from a troubled past to a 'healed' present, evacuated of colonial agendas, programmes, and relationships. A 1996, six-minute video recording for the Solicitor General entitled simply Healing Lodge includes pastoral shots of Okimaw Ohci, interviews with inmates and administrators, as well as footage of prison staff cooking fry-bread. Midway through, an unnamed prisoner describes how programmes at the facility have helped her, especially on a spiritual level. During 
her interview, the film cuts to Canadian Broadcasting Corporation (свС) footage from 1994, taken at P4W. In grainy black and white, prison guards stripsearch an inmate while she screams. The woman bears a strong resemblance to the previous interviewee, to whom the camera returns for a first-hand account of a 'vision quest' at the lodge.

Свс's footage of $\mathrm{P} 4 \mathrm{~W}$ is notorious. The 1994 broadcast unveiled the horrific conditions in the prison, and essentially forced the government to respond. It did so by initiating the Arbour Commission of Inquiry, which later produced a report calling for 'legal safeguards' and a 'culture of rights' in the prison system (Hannah-Moffat and Shaw 2000, 24). Most of the commission's recommendations have been ignored, but the СвС video itself has proven useful insofar as it revealed the atrocious conditions in $\mathrm{P} 4 \mathrm{~W}$ and undoubtedly contributed to its closure. In the context of Healing Lodge, however, the footage supports a temporalised dichotomy between $\mathrm{P} 4 \mathrm{~W}$ and Okimaw Ohci. The 'vision quest' inmate describes what she hopes to achieve during her stay at Okimaw Ohci: overcoming the traumas of $\mathrm{P} 4 \mathrm{~W}$; grappling with the consequences of having a mother who could not provide for her; and learning to heal from the violence she experienced while living on the street. The video thus constructs parallel normative trajectories between the State and the individual: the individual graduates from strip search to vision quest, while the State, enlightened and inspired, purports to surrender its old draconian tendencies. In fact, Healing Lodge's envisioned recognitionist narrative strives to bind the prisoner and prison in a shared destiny: the prison will adapt to the particular needs of federally-sentenced women, so long as Indigenous women concur with their pathologisation as broken individuals. Healing Lodge thus construes CsC as having moved from a past that was plagued by penal programmes that were well-intentioned but poorly implemented, to a modern present in which it is prepared to do the 'right thing' in order to 'move on'.

Healing Lodge embodies a temporal logic that is characteristic of the colonial present: Indigenous people claiming a place in an ideal and prosperous future must let go the troubles of yesteryear - presented as the growing pains of an ultimately 'inclusive' nation - and relish the full embodiment of the modern subject, who is permitted to exhibit signs of difference that do not undermine the sovereignty of the State. Wendy Brown stipulates that 'progressive historiography' - much like Coulthard's critique of Marx's 'normative developmentalism' $(2014,11)$ - 'ratifies the dominance of the bourgeoisie by tacitly articulating an ideology that erases the condition of the defeated or the oppressed in the name of a historical automatism' $(2001,163)$. In order to develop strategies that undermine the ideological power of 'progressive historiographies' - of which 
colonial temporalities are a type - Brown adopts Walter Benjamin's conception of historical narrative as an 'imagistic' memory that constitutes a dialectic between teleology and memory, thus disrupting the knowability of the present (p.166). In other words, embracing a conception of the present that is infused with multifarious elements of myriad and perhaps contradictory pasts has the potential to unseat domineering notions of 'progress' that support injustices and inequalities in the present. Brown's analysis invites us to view the Canadian settler-colonial State as 'haunted', 'disquieted', and 'disoriented' by the past, which necessitates that it perpetually affirm the 'colonial present.' However, it is not clear whether a more legitimate temporality - the historiography that the 'colonial present' elides - can introduce the 'permanent open-endedness of meaning and limits of mastery' needed to subvert colonialist accounts of history (p.152). Rather, the temporalising element of carceral recognition seems to enact a rationalising force, bolstering settler-colonialism by using incarcerated Indigenous women as vessels for the contradictions and exclusions of hegemonic notions of history.

In terms of its temporal and historiographical implications, carceral recognition is a pre-emptive/reactionary response to the possibility that things might not always go 'as they ought to' (Brown 2001, 153), due to feminist and anti-prison activism, for example. The 'normative developmentalism' that csc imposes actually attempts to define the present by 'fixing' the past - both in terms of a repair as well as an imposed stasis - which works to dismiss the ways in which the past informs the present. Hegemonic temporalities anticipate prospective divergences and adapt accordingly. In the case of Okimaw Ohci, csc preemptively affirms the future by pathologising those who presently embody the history but also the persistence of Canada's settler-colonial practices. Carceral recognition thus locates the disruption potentiated by alternate conceptions of the past and present in those who fail to comply with the historical and teleological ideologies that sustain the 'colonial present': women whose personal lives do not reflect the 'improvements' offered by the progressive State are not ideal citizens and thus do not deserve inclusion. Put bluntly, they are excluded from State documentaries, the unfortunate but necessary outcasts of the evolution towards social inclusion shared by all Canadians.

Rerouting the resistant potential of alternate temporalities and 'spectral pasts' (Brown 2001, 145) through incarcerated and marginalised Indigenous women concretises the settler-colonial relationship and rationalises the tension of the unknowable and unstable present. Specifically, csc's recognitionist policies require federally-sentenced Indigenous women to embody the effects of settlercolonialism while complying with a normative temporality in which settler- 
colonialism is situated in the past: the consequent, paradoxical resonances of the 'colonial present' are transmuted as evidence of the supposedly inherent brokenness of 'criminal' Indigenous women. It is not that Okimaw Ohci and its attendant 'colonial present' displace a true version of the past. Rather, csc uses the facility to impose a normative order upon the relationship between the past and the present in Canada, via the application of exclusionary risk assessments and the rhetoric of 'personal responsibility', in order to actualise a future in which the current settler-colonial relationship remains intact.

\section{RISKY CRIMINALS AND RESPONSIBLE SUBJECTS}

Okimaw Ohci's risk classification is of particular concern for conceptualising how csc constrains access to the lodge, and thereby manipulates inmates through a complex process of responsibilisation. In 2003, the NWAC issued a position paper stating that while Okimaw Ohci is a 'laudable experiment', the lodge can only accommodate a small number of women at any one time. This leaves most federally-sentenced Indigenous women - between 60 and 120 - in inappropriate facilities, such as those 'built and staffed for male prisoners', or 'segregated within the women's regional federal prisons' (McIvor and Johnson 2003, 22-23). Moreover, the facility frequently operates below capacity because it will not accept prisoners classified as 'high risk' (Crutcher and Trevethan $2002,25)$. The exclusion of 'high risk' inmates from the lodge is of particular concern because of the frequency with which csc identifies Indigenous women as such. According to the ocI, 80 per cent of Indigenous prisoners score as maximum or medium security upon their initial prison intake assessment, versus 66 per cent of non-Indigenous offenders. In fact, Indigenous women are classified at maximum security ratings in greater proportion than the general population, including Indigenous men: in 2007 Indigenous women 'made up $45 \%$ of maximum security federally sentenced women, $44 \%$ of medium and only $18 \%$ of minimum' (Mann 2009, 16).

State initiatives that recognise and accommodate Indigenous women prisoners by meting out 'healing' also pathologise individual women via the use of risk factors. Individual risk factors are commonly identified as an individual's flaws rather than the effects of a destructive present underwritten by oppressive practices of a colonising nation-state. In response to assertions that Indigenous prisoners are unfairly assigned higher security ratings, one government-sponsored report claims that 'Aboriginal women offenders' display behaviours and tendencies that are 'well-established predictors and correlates of institutional maladjustment and post-release reoffending' (Verbrugge and Blanchette 2002, 12). By contrast, scholars concerned with settler-colonial oppression in Canada 
maintain that hegemonic assessments of criminality - at Okimaw Ohci and at 'conventional' prisons - discriminate against Indigenous women by default because such categorisation frameworks are the product of an inappropriate, imported legal system. csc discreetly adopts 'a sense of taking responsibility that is lopsided from the Aboriginal point of view because it is solely offender based' and focuses on the 'wrong-doer' working to 'become right again' (Monture-Angus 2000, 55). Feminist studies likewise support claims that risk assessments have undermined the objectives of TFFsw, and scholars are especially suspicious of 'revisionist' accounts within the prison system that refuse to acknowledge that patriarchal and gender-based assumptions operate within prison policy (Shaw and Hannah-Moffat 1999, quoted in Hannah-Moffat and Shaw 2000, 16). In effect, Csc's insistence on locating criminality in an inability of Indigenous women to 'take responsibility' for the effects of settler-colonial injustice grants implicit consent for the State to intensify the penal system and thereby maintain its paternalistic relationship to Indigenous peoples.

One csc report insists that 'Aboriginal communities' tend to refuse responsibility for criminal behaviour, and instead opt for treatment rather than 'admit their own responsibility' (Canada Government 1998). The report elaborates, insisting that 'key ingredients in the creation of a criminal' include a 'lack of adequate parenting' and problems with addiction - pathologies that the report associates with Indigenous people and communities, which it claims 'are lacking in discipline' (p.28). The idea that Indigenous women are inherently riskier than other women dovetails with the State demand that such women need to take ownership of the conditions that led to their incarceration. Indeed, Canadian bureaucrats have long seen responsibilisation as a tool for spreading the individualist ideals of the State to the Indigenous peoples within its borders, dating to the inception of the Indian Act (1876), ${ }^{5}$ if not before. In 189o, the Commission of Indian Affairs wrote that Indigenous peoples must be taught 'individual responsibility' in order to break them from their communalism and land-based practices, so that the State might alienate them from their lands with greater ease (Canada Government 1890, 165). Csc's policies echo the ideologies that informed some of Canada's earliest attempts to dominate and control Indigenous peoples, suggesting that carceral responsibilisation is a component in a larger, historic colonial apparatus designed to establish the authority of the colonial state and gain control over the land and its resources. Okimaw Ohci is thus a racial technology of 'conquest and domination' (Razack 2002,5 ), with, crucially, a particular spatial dimension that facilitates domination while simultaneously constituting Indigenous peoples as inherently in need of supervision, management, and correction. 
Despite the oppressive effects of responsibilisation, many feminist and antiprison activists are keen to promote the imperatives of taking responsibility, as evidenced in Karlene Faith's assertion that rehabilitation and 'healing' depends primarily upon 'the will of the individual' $(2006,300)$. That even some of the most ardent advocates for change are inclined to promote the value of individual responsibility perhaps speaks to the seductiveness of understanding criminality through a paradigm of individualistic ideologies. Indeed, the rhetorical link between personal responsibility and personal prosperity has currency both in the penal system as well as in neoliberal societies more broadly. Like the maintenance of market values, improving incarceration is thought to depend upon 'each individual's desire to govern their own conduct freely in the service of the maximization of their happiness and fulfilment that they take to be their own' (Rose 1996, 59). Csc has a duty to enable Indigenous peoples to improve themselves, rather than 'civilising' them by force. The Canadian justice system thereby operates, supposedly, as a 'partner and animator rather than provider and manager' (Rose 2000,327), enabling individuals 'to choose, in a way and to a degree never envisaged by normative disciplinarity - but if those choices lead into criminal offending, they must take the burden of their choice' (O’Malley 1994, quoted in Pratt 1997, 186).

While csc claims that Indigenous women need to take responsibility if they hope to achieve 'healing' and achieve a lower risk rating, the institution itself seems to be the largest obstacle in their efforts to do so. In a 1999 follow-up report to Creating Choices, Sky Blue Morin reports that federally-sentenced Indigenous women rated at maximum security are frequently denied access to programmes as punishment for refusing to 'conform' and to 'obey csc staff'. This lack of participation means that most federally-sentenced Indigenous women 'remain incarcerated longer, many until their statutory release dates' (Morin 1999, Ch. 4, n.p.). Over three-quarters of the prisoners interviewed recounted that they were accused of being 'manipulative and argumentative' when they speak in a direct and straightforward manner. The same number of women stated that 'they were not given a chance. An application for transfer to the [Okimaw Ohci] Healing Lodge was never processed', and despite remaining free of extra charges and avoiding conflicts, CsC staff informed many Indigenous women prisoners that 'their attitudes were not good enough'. Only twelve per cent of maximum-security Indigenous women reported that they received 'support from staff and program facilitators' to attain a reduced security level (Ch. 5, n.p.). Despite csc's valorisation of personal responsibility, even the most determined of federally-sentenced Indigenous women are systematically denied the chance to prove that they deserve to serve their sentence at Okimaw Ohci. 
Uncertainty as to whether csc will allow many federally-sentenced Indigenous women to ever gain access to Okimaw Ohci does not undercut its status as the (perceived) best choice for Indigenous women in federal prison. Inmates' frustrations and ongoing efforts speak to the ideological force exerted by the lodge, likely derived from the prevailing carceral discourse, which construes access to Indigenous-specific penal programming as a desirable - even natural - alternative to 'conventional' prisons, like P4W. Sociological, psychologi$\mathrm{cal}$, and criminological studies regularly conclude that 'Aboriginal spirituality programs' in prisons are 'the best chance for many Aboriginal inmates to deal with the trauma of their past and the stresses of their prison existence and to define a new life course' (Waldram 1997, 219; emphasis added). For example, Morin's interviewees insisted, unanimously, that 'Aboriginal ceremonies need to be recognized as part of the Correctional plan (for their healing effects in dealing with the Aboriginal women)' (1999, Ch. 5, n.p.). In accordance with Coulthard's theory, the healing lodge thus seems to exert a subjectifying force whereby Indigenous women in prison seek out and covet the recognition 'imposed or bestowed' on them by csc (Coulthard 2014, 31), such as access to State-sanctioned 'healing. The subjectifying force of carceral recognition also means that those most oppressed by the penal system risk internalising the ideals to which they are subordinated.

In fact, carceral recognition cuts two ways: it subjectifies Indigenous women in prison, while also affirming the subject positions held by members of settler society, vis-à-vis the carceral State. Okimaw Ohci is more than just an 'abstract site into which undesirables are deposited' (Davis 2003, 16). This is clear in the binary between the 'healable' and 'unhealable' designations that access to Okimaw Ohci both enforces and depends upon, which echoes the classic colonial split between 'noble' and 'ignoble savage'. Such binaries reinstate 'the very configurations of colonialist, racist, patriarchal state power that Indigenous peoples' demands for recognition have historically sought to transcend' (Coulthard 2014, 3). Specifically, carceral recognition distinguishes between Indigenous women who, to repurpose Stuart Hall's analysis, are 'unsophisticated [...] living in a state of Nature' $(1992,311)$, meaning that they are, in their ideal state, simple, peaceful, and easy to govern. Hence, the 'healable' indigene simply needs to be brought up to speed. After all, she follows the same developmental trajectory as Western culture, albeit at an earlier point, unlike her counterpoint, the 'ignoble savage', who travels a divergent path that will never lead to civilisation and who is, therefore, unsuitable for membership in mass society (Hall 1992, 311-12). When Okimaw Ohci and CsC require Indigenous prisoners to perform docility and accept personal responsibility, they not only interpellate the women as subjects of the State, but do so in a way that will seem axiomatic 
to those steeped in the logics of civility and criminality that underpin much of Western settler society. Hence, carceral recognition defends 'Canada's assumed sovereignty' (Coulthard 2014, 41) by actively reconditioning and reproducing the icons and relationships that are familiar to the colonial consciousness, as well as colonial conceptions of temporality. Carceral recognition envisions Indigenous women as anachronistic in their brokenness: their inability to shed the evidence of settler-colonialism's 'past traumas' means that they, ostensibly, persist in demonstrating the effects of a system that is, supposedly, no longer.

CONSETELLATIONS OF RECOGNITION AND REFORM: Imagining Alternatives

CsC's recognitionist programming ensures that all discussions pertaining to the particular needs of Indigenous women in prison remain centred on creating adapted forms of penality. Calls for recognition-based reform carry the problems of working for change in an era of colonial recognition politics and the problems that are inherent to prison reform: both might produce, as Patchen Markell asserts, 'concrete improvements in the conditions of life of the people' that they 'aim to benefit', but both are ultimately 'ill-equipped to diagnose and respond effectively to the underlying relations of subordination' $(2003,17)$. Advocating for recognition-based reform is 'especially prone to become complicit with injustice' (Markell 2003, 17), as was the case when csC adapted the demands of the TFFSW to produce 'a better prison system' (Davis 2003, 20; emphasis in original). Additionally, as prison abolitionists frequently warn, working to change the prison system can sometimes mean failing to theorise 'other possibilities' (Hannah-Moffat and Shaw 2000, 26). Indeed, critiques that focus solely on reforming penal institutions inadvertently entrench the penal system, and 'help to produce the stultifying idea that nothing lies beyond the prison' (Davis 2003, 20). In terms of incarceration in the service of settler-colonialism, carceral recognition naturalises the prison in perpetuity by constructing an ideological link between the desirability of facilities like Okimaw Ohci, the embeddedness of the prison system in the settler-colonial State, and the psyche of the settler-colonial society.

Given the degree to which carceral recognition effectively obfuscates the lived effects of ongoing settler-colonialism on Indigenous prisoners, the recognitionist reforms of the Canadian penal system form the foundation for the types of negotiations and political interactions that Coulthard describes. What remain to be seen are the implications of a critique of settler-colonialism that does not account for the role of carceral recognition (or recognition of Indigenous women's difference in the penal system) in framing objectives and maintaining asymmetrical relations between Indigenous peoples - both 'inside' and 
'outside' - and the State. Moreover, because carceral recognition politics takes the shape of - and even doubles as - prison reform, critiquing Okimaw Ohci based on the limited and troubling ways in which it accommodates 'Indigenous difference' is difficult, in large part due to the 'thinkability' of the prison system. As Angela Davis writes, 'On the whole, people tend to take prisons for granted. It is difficult to imagine life without them. At the same time, there is reluctance to face the realities hidden within them, a fear of thinking about what happens inside them' $(2003,15)$. Conversely, disproportionate representation, social and systemic discrimination, and a history of the State deploying a plethora of institutions to enact exclusion, disenfranchisement, and assimilation mean that imprisonment is a conceivable reality for Indigenous peoples in Canada, both incarcerated and 'free'. Indigenous people's heightened familiarity with the penal system suggests that the recognitionist policies of Okimaw Ohci provide much-needed hope in the everyday lives of some federally-sentenced Indigenous women. The TFFSW intended to produce more options - hence the title of Creating Choices - for federally-sentenced Indigenous women. Given the possibility that recognition will appeal to - and even benefit - those who have the most to gain from improvements to the existing system, demanding that marginalised people must disentangle themselves from a system within which they are simultaneously accommodated and entrapped, risks further burdening those who bear the more explicitly violent effects of settler-colonialism, such as Indigenous women in prison.

One point of divergence between the critique of carceral recognition developed here and Coulthard's theory comes from the notion that contemporary colonialism works primarily through a benevolent politics. For many, the prison system proves that colonialism has never ceased using violence and coercion. In 'The Colonialism of Incarceration', Robert Nichols writes that the transition from the "hard infrastructure" of military operations and residential schools to the "soft infrastructure" of cultural recognition and accommodation is 'coeval with the growth of a whole shadow system of hard infrastructure, of which the prison system is emblematic $(2014,448)$. However, while illuminating the relationship between institutions like the penal system and Canada's tendency towards State-sanctioned apologies and self-government agreements is important, distinguishing between 'hard' and 'soft infrastructure' perhaps draws too clear a line between the two. As Sarah Hunt points out in her response to Red Skin, we must learn to see colonialism working on many levels at once - the interpersonal alongside the political - lest we end up seeing 'gendered violence, police brutality, carcereality of everyday life, deaths of kids in care and willful negligence of [Indigenous] communities as not politically significant' (2015, 4). Likewise, Okimaw Ohci reveals that the prison system reforms and adapts 
in such a way that benevolent recognition and coercion are actually coextensive. The lodge's ostensible 'soft infrastructure' is interwoven with csc's ability to punish non-compliant and 'difficult' Indigenous women without redress (Hannah-Moffat and Shaw 2000, 24), exemplified in the relationship of 'healing' to pathologisation. Of course, 'prisons are places where acts of abuse and intimidation' are not only commonplace but seen as somehow necessary to rehabilitate those who have come into conflict with the criminal justice system, which 'collides with the visionary nature of what is aspired to at the Healing Lodge' (Hayman 2006, 228). However, the apparent conflict between 'abuse' and accommodation at Okimaw Ohci is less a contradiction than it is emblematic of the productive interplay between settler state objectives and individual subjectivity that is vital to the workings of the Canadian penal system. Okimaw Ohci serves multiple purposes: it is a much-needed alternative to the horrors of $\mathrm{P} 4 \mathrm{~W}$ as well as a mechanism of State power.

If contemporary settler-colonialism functions by disguising the interlocking oppressive social relations', institutional systems, and modes of subjectification 'that constitute it' (Coulthard 2014, 15), then turning away from the prison might recontextualise facilities like Okimaw Ohci in a broad, multivalent network of colonial - and colonising - institutions, and thus support the establishment of robust modes of Indigenous resurgence. Prisons exist in a constellation of institutions dedicated to separating individuals from their communities in processes of forced assimilation' (Faith 2006, 288), where absorption into settler society is at once compulsory and impossible, regardless of whether it is actually desirable. By many accounts, Indigenous women experience 'dislocation and disconnection' - psychologically and socially - at the hands of myriad institutions, which include not only the prison but numerous other arms of the State, such as child welfare and social service agencies (Monture-Angus $2000,52)$, as well as education and health care systems. These are sites where Indigenous women encounter profound racism, compounded by the popular assumption that Indigenous peoples prosper when they learn to 'fit in'.

Working towards a 'moratorium on prisons' might force policy-makers and stakeholders to consider ' what else can be done to deal with the troubles that women become involved in' (Hannah-Moffat and Shaw 2000, 26; emphasis in original), and a distinctly decolonial approach to abolition must be wary of the notion that other institutions - or even 'the community' - are inherently un-oppressive, given the fact that they are not prisons per se. Rejecting the prison does not address the fact that incarceration is not the only - or even the primary - locus of oppression for many Indigenous women. Nevertheless, the penal system's unique capacity to adapt to, recognise, and reform in response 
to contemporary assertions of Indigenous sovereignty suggests that it plays a particular role in the network of programmes and practices that make up the settler-colonial system in Canada.

\section{CONCLUSION}

Failing to attend to the infinitely complex web of discourses, practices, and histories that shape the daily lives of federally-sentenced Indigenous women enacts a compartmentalisation - and, potentially, a re-pathologisation - of inequality and injustice that mimics the objectives of both the prison system and the settler-colonial State. Such a position also exempts us from asking some important questions: How do we come to think about the colonial prison system and its captives, and how does this thinking make the present inhabitable? Who must be evicted from the present in order to render it livable, according to the terms of settler society? Formulating a distinction between the good of the public and the living conditions of incarcerated Indigenous women also reveals a paradox: can a present actualised by the eviction of marginalised individuals ever be good for anyone, and does an affirmative response legitimise the current power dynamics in Canada? Rather than selecting between the rights of the individual and the good of the 'whole', we can instead consider what can happen when we depathologise Indigenous women and fully begin to scrutinise the machinations and effects of settler-colonialism, stripped of its favourite disguises in recognitionist policies.

\section{ACKNOWLEDGEMENTS}

This research was made possible by a Master's scholarship and a Doctoral scholarship, both generously provided by the Social Sciences and Humanities Research Council of Canada (sshrc) as well as an Ontario Graduate Scholarship (ogs) awarded by McMaster University.

\section{NOTES}

1 Margaret Boyce is a settler living on Haudenosaunee, Mississauga, and Algonquin lands who is currently working towards a PhD in English and Culture Studies at McMaster University. Her research interests include Indigenous sovereignty, carceral societies, settler-colonial studies, critical animal studies and risk and security society. She is currently developing a dissertation that critically examines Canada's promotion of Inuit art within the context of the settler state asserting psychic, economic and political sovereignty over the Arctic.

Email: boycem3@mcmaster.ca 
2 Coulthard develops his theory using Frantz Fanon's Black Skin, White Masks, with reference to Hegel's 'master/slave' dialectic. Conversely, Charles Taylor's 'The Politics of Recognition' (1994), which is widely cited in discussions of recognition, takes up different questions than Coulthard. Taylor invokes a concept in which misrecognition of identity 'imprison[s]' subjects 'in a false, distorted, and reduced mode of being' (p.25). Attending to the implications of recognition for identity based on this theory risks advancing claims that are beyond the scope of this paper (see Markell 2003, Ch. 1).

3 The 2016 annual report by the Office of the Correctional Investigator (oci) states that, while Indigenous people make up 4.3 per cent of Canada's population, 35 per cent of women incarcerated in federal prisons are Indigenous (Sapers 2016). Canada's rates of Indigenous incarceration mirror those of other settler-colonial nations like the United States, Australia, and Aotearoa (New Zealand), the latter of which currently has a prison population that is over 50 per cent Māori (New Zealand 2016) despite this community representing 15 per cent of the country's total population.

4 In 2011, CsC introduced beds for women at a Section 81 Healing Lodge, the Buffalo Sage Healing Centre in Edmonton (Sapers 2012, 14).

5 The Indian Act codifies Canada's relationship to Indigenous peoples, detailing what defines a 'status Indian', who lives on reserves, and what they can do, and implemented a now-defunct 'pass system' for Indigenous people to leave reserves. The act has undergone multiple rounds of revisions since its inception in attempts to correct some of its more blatantly oppressive and discriminatory provisions, but it is still commonly referred to as one of the most racist pieces of legislation in the world (see Bartlett 1988).

\section{REFERENCES}

Adelberg, Ellen, and Claudia Currie, eds. 1993. In Conflict with the Law: Women and the Canadian Justice System. Vancouver: Press Gang.

Adelberg, Ellen, and the Native Women's Association of Canada. 1993. 'Aboriginal Women and Prison Reform'. In In Conflict with the Law: Women and the Canadian Justice System, edited by Ellen Adelberg and Claudia Currie, 76-92. Vancouver: Press Gang.

Alfred, Taiaiake. 2005. Wasáse: Indigenous Pathways of Action and Freedom. Toronto: University of Toronto Press. 
-2009. Peace, Power, Righteousness: An Indigenous Manifesto. 2nd ed. Don Mills, ON: Oxford University Press.

Assembly of First Nations (AFN). 2005. Our Nations, Our Governments: Choosing our Own Paths. Ottawa: Assembly of First Nations.

Bartlett, Richard. 1988. The Indian Act of Canada. Regina: Native Law Centre, University of Saskatchewan.

Brown, Wendy. 2001. Politics Out of History. Princeton, NJ: Princeton University Press.

Canada Government. 189o. 'Report of Commissioner Reed 1889.' In Sessional Papers of the Dominion of Canada: Volume 10, Fourth Session of the Sixth Parliament, session 1890, 158-173. Ottawa: B. Chamberlin.

-1992. Corrections and Conditional Release Act. Ottawa: Correctional Service of Canada. Last amended 17 June 2016, from http://laws-lois.justice. gc.ca/PDF/C-44.6.pdf

- 1998. 'Issues in Urban Aboriginal Correction'. Ottawa: Correctional Service of Canada. Accessed 1 June 2015 from http://publications.gc.ca/collections/ collection_2016/sp-ps/Js5-1-17-1998-eng.pdf

Carlen, Pat. 2002. 'Carceral Clawback: The Case of Women's Imprisonment in Canada'. Punishment and Society 4 (1):115-21.

Coulthard, Glen Sean. 2014. Red Skin, White Masks: Rejecting the Colonial Politics of Recognition. Minneapolis: University of Minnesota Press.

Crutcher, Nicole, and Shelley Trevethan. 2002. 'An Examination of Healing Lodges for Federal Offenders in Canada'. FORUM on Corrections Research 6 (1):5254 .

Davis, Angela. 2003. Are Prisons Obsolete? New York: Seven Stories Press.

Faith, Karlene. 2006. 'Prison as Colonization'. In 13 Women: Parables from Prison, edited by Karlene Faith and Anna Near, 274-308. Vancouver: Douglas \& McIntyre.

Faith, Karlene, Mary Gottfriedson, Cherry Joe, Wendy Leonard, and Sharon 
McIvor. 1990. 'Women in Canada: A Question for Justice'. Social Justice $17(3): 167-88$.

Faith, Karlene, and Kim Pate. 200o. 'Personal and Political Musings on Activism: A Two-Way Interview'. In An Ideal Prison?: Critical Essays on Women's Imprisonment in Canada, edited by Kelly Hannah-Moffat and Margaret Shaw, 136-46. Halifax: Fernwood Publishing.

Fortin, Doris. 2004. Program Strategy for Women Offenders. Ottawa: Correctional Service of Canada.

Foucault, Michel. 1979. Discipline and Punish: The Birth of the Prison. New York: Vintage Books.

Hall, Stuart. 1992. 'The West and the Rest: Discourse and Power'. In The Formations of Modernity: Understanding Modern Societies, edited by Stuart Hall and Bram Gieben, 275-329. Maidenhead: Open University Press.

Hannah-Moffat, Kelly, and Margaret Shaw. 200o. An Ideal Prison?: Critical Essays on Women's Imprisonment in Canada. Halifax: Fernwood Publishing.

Hayman, Stephanie. 2006. Imprisoning Our Sisters: The New Federal Women's Prisons in Canada. Montreal: McGill-Queen's University Press.

Healing Lodge. 1996. Directed by James Gray. Ottawa: Public Safety Canada Library: Productions XIII. DVD.

Hunt, Sarah. 2015. 'Violence, Law and the Everyday Politics of Recognition'. Comments on Glen Coulthard's Red Skin, White Masks. Presented at the Native American and Indigenous Studies Association (NAISA), Washington, DC, 6 June.

Mann, Michelle M. 2009. Good Intentions, Disappointing Results: A Progress Report on Federal Aboriginal Corrections. Ottawa: Office of the Correctional Investigator Canada.

Markell, Patchen. 2003. Bound by Recognition. Princeton, NJ: Princeton University Press.

McIvor, Sharon D., and Ellisa C. Johnson. 2003. Detailed Position of the Native Women's Association of Canada on the Complaint Regarding the Discrimina- 
tory Treatment of Federally Sentenced Women by the Government of Canada Filed by the Canadian Association of Elizabeth Fry Societies on May 05, 2003. Ottawa: NWAC.

McKegney, Sam. 2005. 'From Trickster Poetics to Transgressive Politics'. Studies in American Indian Literatures 2 (17): 79-113.

Monture-Angus, Patricia. 200o. 'Aboriginal Women and Correctional Practices: Reflections on the Task Force on Federally Sentenced Women'. In An Ideal Prison?: Critical Essays on Women's Imprisonment in Canada, edited by Kelly Hannah-Moffat and Margaret Shaw, 52-60. Halifax: Fernwood Publishing.

Morin, Sky Blue. 1999. Federally Sentenced Aboriginal Women in Maximum Security: What Happened to the Promises of 'Creating Choices'? Ottawa: Correctional Service of Canada. Accessed 29 October 2016 from http://www. csc-scc.gc.ca/publications/fsw/skyblue/toce-eng.shtml

New Zealand. 'Prison Facts and Statistics - December 2016'. Wellington: Department of Corrections. Accessed 10 March 2017 from http://www.corrections. govt.nz/resources/research_and_statistics/quarterly_prison_statisics/prison_stats_december_2016.html

Nichols, Robert. 2014. 'The Colonialism of Incarceration'. Radical Philosophy Review $17(2)$ : 435-55.

Pratt, John. 1997. Governing the Dangerous: Dangerousness, Law and Social Change. Sydney: Federation Press.

Razack, Sherene. 2002. Race, Space, and the Law: Unmapping a White Settler Society. Toronto: Between the Lines Publishing.

Rose, Nikolas S. 1996. 'Governing “Advanced” Liberal Democracies'. In Foucault and Political Reason: Liberalism, Neo-liberalism, and Rationalities of Government, edited by Andrew Barry, Thomas Osborne, and Nikolas S Rose, 37-64. Chicago: University of Chicago Press.

- 2000. 'Government and Control'. British Journal of Criminology 40:321-39.

Sapers, Howard. 2012. 'Spirit Matters: Aboriginal People and the Corrections and Conditional Release Act. Final Report of the ocr'. Ottawa: Office of the Correctional Investigator. Accessed 15 October 2016 from http://www.oci-bec. 
gc.ca/cnt/rpt/oth-aut/oth-aut20121022-eng.aspx

2016. Annual Report of the Office of the Correctional Investigator 2015-2016. Ottawa: Ministry of Public Safety. Accessed 9 March 2017 from http://www. oci-bec.gc.ca/cnt/rpt/pdf/annrpt/annrpt20152016-eng.pdf

Shaw, Margaret, and Kelly Hannah-Moffat. 1999. 'Women and Risk: A Geneology of Classification'. Paper presented at the British Criminology Conference, Liverpool, 13-16 July.

Smith, Andrea. 2014. 'Native Studies at the Horizon of Death: Theorizing Ethnographic Entrapment and Settler Self-Reflexivity'. In Theorizing Native Studies, edited by Audra Simpson and Andrea Smith, 207-34. Durham, NC: Duke University Press.

Task Force on Federally Sentenced Women (TFFsw). 1990. Creating Choices: The Report of the Task Force on Federally Sentenced Women. Ottawa: Correctional Service of Canada.

Taylor, Charles. 1994. 'The Politics of Recognition'. Multiculturalism: Examining the Politics of Recognition, edited by Amy Gutmann, 25-74. Princeton, N.J.: Princeton University Press.

Verbrugge, Paul, and Kelley Blanchette. 2002.'The Validity of the Custody Rating Scale for the Initial Security Classification of Aboriginal Women'. FORUM on Corrections Research 6 (1):10-12.

Waldram, James B. 1997. The Way of the Pipe: Aboriginal Spirituality and Symbolic Healing in Canadian Prisons. Peterborough, ON: Broadview Press.

Zellerer, Evelyn. 1992. 'Native Spirituality Behind Bars: A Policy Proposal.' Canadian Journal of Native Studies 2 (2):251-68. 